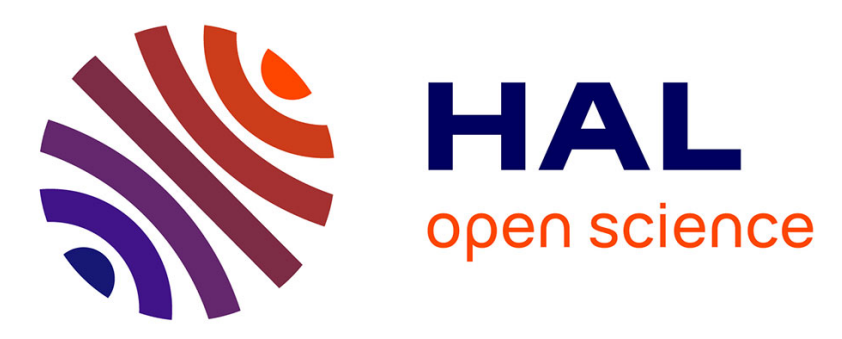

\title{
Synthesis, optical and redox properties of regioisomeric benzoheterocycles-fused pyrene
}

\author{
Anabella Mocanu, Rózsa Szücs, Elsa Caytan, Thierry Roisnel, Vincent \\ Dorcet, Pierre-Antoine Bouit, László Nyulászi, Muriel Hissler
}

\section{To cite this version:}

Anabella Mocanu, Rózsa Szücs, Elsa Caytan, Thierry Roisnel, Vincent Dorcet, et al.. Synthesis, optical and redox properties of regioisomeric benzoheterocycles-fused pyrene. Journal of Organic Chemistry, 2019, 84 (2), pp.957-962. 10.1021/acs.joc.8b02884 . hal-01971375

\section{HAL Id: hal-01971375 \\ https://hal.science/hal-01971375}

Submitted on 7 Jan 2019

HAL is a multi-disciplinary open access archive for the deposit and dissemination of scientific research documents, whether they are published or not. The documents may come from teaching and research institutions in France or abroad, or from public or private research centers.
L'archive ouverte pluridisciplinaire HAL, est destinée au dépôt et à la diffusion de documents scientifiques de niveau recherche, publiés ou non, émanant des établissements d'enseignement et de recherche français ou étrangers, des laboratoires publics ou privés. 


\title{
Synthesis, optical and redox properties of regioisomeric benzohetero- cycles-fused pyrene.
}

\author{
Anabella Mocanu, ${ }^{\dagger}$ Rózsa Szücs, ${ }^{\dagger,}$ Elsa Caytan,${ }^{\dagger}$ Thierry Roisnel, ${ }^{\dagger a}$ Vincent Dorcet,${ }^{\dagger}$ Pierre-Antoine \\ Bouit, *† László Nyulászi, *\$ Muriel Hissler*† \\ ${ }^{\dagger}$ Univ Rennes, CNRS, ISCR - UMR 6226, ScanMat - UMS 2001, F-35000 Rennes, France ; ${ }^{\ddagger}$ Department of Inorganic and \\ Analytical Chemistry, Budapest University of Technology and Economics, and MTA-BME Computation Driven Chemistry \\ Research Group. Szt. Gellert ter 4 H-1111 Budapest, Hungary.
}

Supporting Information Placeholder

ABSTRACT: A new synthetic route toward the synthesis of benzo[b]phospholesand benzo[b]siloles-fused pyrenes using a transition metal-catalyzed $\mathrm{C}-\mathrm{H}$ bond activation is described. The compounds were fully characterized including X-ray diffraction. A combined experimental and theoretical study shows that both the heteroatom and the substitution pattern impact the optical and redox properties.

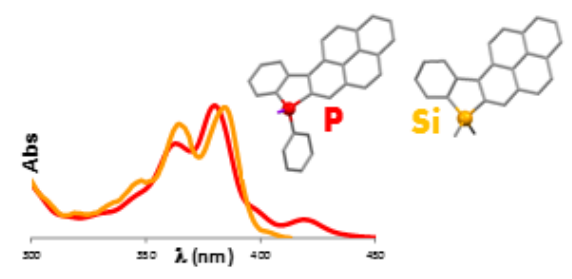

Polycyclic aromatic hydrocarbons (PAHs) have demonstrated to be highly versatile materials for the development of efficient electronic devices. ${ }^{1}$ In particular, pyrene and its derivatives have proven to be appealing materials for multiple applications (i.e. as optical brightener Fluolite XMF ${ }^{\mathrm{TM}}$, reactive dye C.I. Direct Blue 109 or fluorescent dye Pyranine) due to their unique photophysical and supramolecular properties (high fluorescent quantum yields, relatively long fluorescence lifetimes, excimer/exciplex formation). ${ }^{2}$

The tuning of the optical and electronic properties of pyrene derivatives is a key issue to diversify the applications of these materials. This led to a creative molecular engineering involving the development of new synthetic approaches for the functionalization of pyrene, the tailoring of substituents and/or the use of heteroatoms ${ }^{3}$ (molecules A-B, Figure 1), or extending the $\pi$-system with fused heterocycles yielding different electronic properties (molecules $\mathbf{C}$ D, Figure 1). For example, regioisomeric sulfur and sulfonyl bridged phenyl-pyrene (molecules $\mathbf{C}$ and $\mathbf{D}$ with $\mathrm{Y}=\mathrm{S}$ or $\mathrm{SO}_{2}$, Figure 1) have been synthesized by Liu, Li et al. ${ }^{4}$ They showed that the physical properties are highly dependent on the position of the substitution on the pyrene skeleton. In this context, the synthesis and the study of optical and redox properties of pyrene-heterocycle analogues (C - D with $\mathrm{Y}=\mathrm{PPh}$ or $\mathrm{SiMe}_{2}$, Figure 1) are of high interest since phosphole and silole rings have strongly different electronic behavior compared to their S-analogs, due to their lowlying LUMO energy levels and the corresponding low aromaticity. ${ }^{5}$

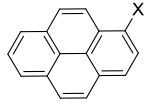

A $X=\mathrm{NR}_{2}, \mathrm{BR}_{2}, \mathrm{CN}, \mathrm{POR}_{2}$

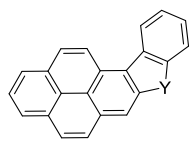

c

$\mathrm{Y}=\mathrm{S} ; \mathrm{SO}_{2} ; \mathrm{NH}, \mathrm{PPh}, \mathrm{P}(=\mathrm{O}) \mathrm{Ph} ; \mathrm{SiMe}_{2}$
Figure 1. Functionalized pyrenes A - B and pyrene-fused heteroles C - D.
In this communication, we present the synthesis based on metalcatalysed $\mathrm{C}-\mathrm{H}$ bond activation of four regioisomeric pyrenebenzo[b]phosphole and -benzo[b]silole derivatives $(\mathbf{C}$ and $\mathbf{D}$ with $\mathrm{Y}=\mathrm{P}(=\mathrm{O}) \mathrm{Ph}$ and $\mathrm{SiMe}_{2}$, Figure 1). We detail also the impact of the nature of the heterocycle and the position of the pyrene substitution on the physical properties by experimental (UV/Vis absorption, fluorescence, cyclic voltammetry) and theoretical studies.

Most of the pyrene derivatives described in the literature are synthesized through Friedel and Craft reactions. ${ }^{4}$ However, this strategy appeared unsuccessful for the incorporation of $\mathrm{P}$ and $\mathrm{Si}$ atoms in these systems. We thus turned to transition metal-catalyzed P$\mathrm{C} / \mathrm{Si}-\mathrm{C}$ bond-formation through $\mathrm{C}-\mathrm{H}$ activation which recently appeared an innovative and powerful synthetic tool to prepare benzoheterocycles. ${ }^{6}$ We decided to apply these methods to synthesize the benzo[b]heterocycles based-pyrene derivatives. Starting from pyrene-1-boronic acid $\mathbf{1}$ (Scheme 1), the phosphine moiety was introduced by means of a Suzuki-Miyaura coupling with (2-bromophenyl)diphenylphosphine (BDP) directly followed by Pd-catalysed cyclization using Chatani's reaction conditions (catalytic amount of $\mathrm{Pd}(\mathrm{OAc})_{2}$, toluene, $\left.160^{\circ} \mathrm{C}, 12 \mathrm{~h}\right) .{ }^{6}$ The first pyrene-fused benzo[b]phosphole 3 was thus prepared in 2 steps (Scheme 1) in moderated yield (45\%). The same synthetic strategy was applied for the preparation of pyrene-fused benzosilole $\mathbf{5}$. The silane was introduced in two steps. First a Suzuki Miyaura coupling between pyrene-1-boronic and bromoiodobenzene (BID) was performed followed by lithiation and quenching with $\mathrm{Me}_{2} \mathrm{SiHCl}$ of the 1-(2iodophenyl)pyrene to afford 4 (Scheme 1). Finally, the cyclization was conducted with catalytic amount of $\mathrm{RhCl}\left(\mathrm{PPh}_{3}\right)_{3}$ applying Takai's conditions to afford 5 in moderate yield (23\%). ${ }^{6 c}$ Similar synthetic strategy was successfully applied for the synthesis of two other regioisomers 6 and 7 (Scheme S1) indicating that the C-H activation is a method of choice for $\mathrm{P}-\mathrm{C} / \mathrm{Si}-\mathrm{C}$ bond-formation on pyrene. Effectively, these reactions can be performed both on activated and also on less activated positions of pyrene. ${ }^{7}$ 


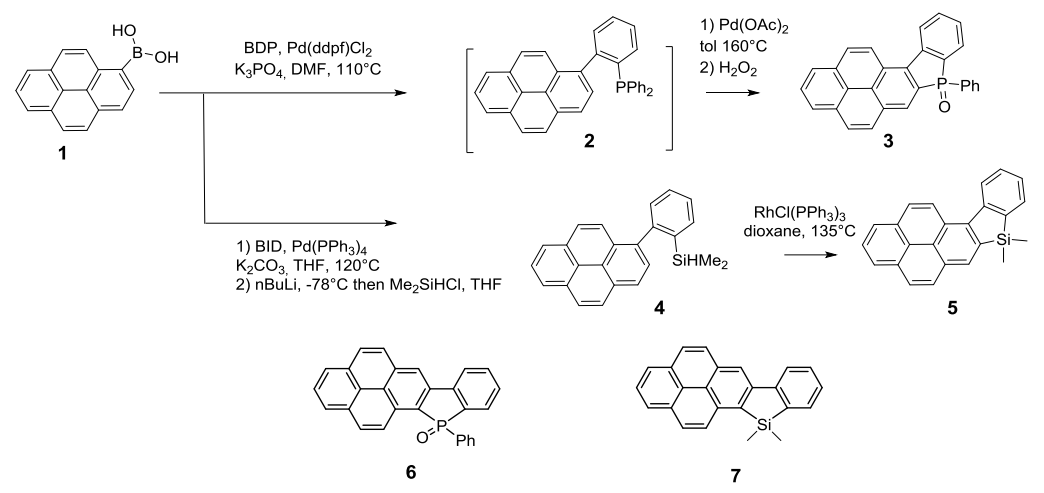

Scheme 1: Synthesis of 3-5 and molecular structures of 6-7.

All the novel pyrene derivatives were fully characterized by multinuclear NMR and HRMS. Furthermore, the structures of 3, 6 and 5 were unambiguously confirmed by X-ray diffraction studies performed on single crystals (see Fig. 2). In all three cases, the bond distances in the heterocycles are classical for benzo[b]phosphole/benzo[b]siloles analogues (see Table S2). ${ }^{5 a}$ Benzo[b]phospholes $\mathbf{3}$ and $\mathbf{6}$, in which the $\mathrm{P}$-atom is stereogenic, crystallize as racemic mixtures (see Fig. S6). In $\mathbf{3}$ and $\mathbf{5}$, where the heteroatom is linked to the 2-position of the pyrene, some distortion is observed in the polycyclic backbone due to $\mathrm{H}-\mathrm{H}$ repulsion in the cove region (maximal deviations from the mean plane are respectively: $0.34 \AA$ and $0.47 \AA$ ). This feature is not observed for 6 (maximal deviation from the mean plane: $0.05 \AA$ ), where the distance between the hydrogens is increased reducing the repulsive interaction. At the intermolecular level, strong differences are observed between the derivatives. The compound $\mathbf{3}$ crystallizes as face-to-face $\pi$-stacked pyrene dimers with an interplanar distance of $3.47 \AA$ (see Fig. 2). No long-range interactions are observed. In the case of $\mathbf{6}, \pi$-stacked dimers are formed $\left(d_{1}=3.51 \AA\right.$, Fig. 2$)$ through interactions of the pyrenic backbone. Those dimers are also involved in $\pi$-stacking interactions ( $\mathrm{d}_{2}=3.58 \AA$, Fig. 2$)$ through partial overlapping of the whole polycyclic framework thus forming infinite $\pi$-columns (see Fig. 2). Even if some other factors linked to the molecular structure and packing might play a role, we believe that the higher planarity of the $\pi$-system might be the driving force for these long-range interactions. Finally, in the crystal structure of $\mathbf{5}$, an infinite network of $\mathrm{CH}-\pi$ interactions $(\mathrm{d}=2.46 \AA$ ) between the pyrene proton at the 5 -position and the pyrenic framework of another molecule is observed. The substitution pattern and the nature of the heteroatom thus strongly influences the molecular packing.

In order to establish structure/properties relationships with benzoheterocycles-fused pyrenes, the optical and electrochemical properties of 3,5-7 were examined in $\mathrm{CH}_{2} \mathrm{Cl}_{2}\left(\mathrm{c}=10^{-5} \mathrm{M}\right)$. Benzoheterocycles -fused pyrenes 3,5-7 exhibit structured absorption in the visible (with a better resolution for 5 and 7) (Fig. 3) which are quite similar to those of pyrene, however showing some red shift. At low energy, benzo[b]phosphole-fused pyrenes 3/6 exhibit well resolved $\mathrm{S}_{1} \leftarrow \mathrm{S}_{0}$ absorption bands, which are mainly attributed to the short-axis-polarized ${ }^{1} \mathrm{~L}_{b}$ transition present in the pyrene unit. ${ }^{3 b}$ The intensity of these weak bands increases with respect to pyrene (Fig. 3), as a consequence of the reduced symmetry. ${ }^{4}$ The intense $\mathrm{S}_{2} \leftarrow \mathrm{S}_{0}$ transition corresponds to the long-axis- polarized ${ }^{1} \mathrm{~L}_{\mathrm{a}}$ transition of pyrene, which is basically a HOMOLUMO transition (vide infra) as previously described on substituted pyrene derivatives. ${ }^{3 \mathrm{~b}}$ In the case of $\mathbf{3}$, there is a slight red shift of these transitions going from hexane to DCM (Fig S2); the red shift is somewhat larger for the ${ }^{1} \mathrm{~L}_{\mathrm{b}}$ than for the ${ }^{1} \mathrm{~L}_{\mathrm{a}}$ band.

Si-containing pyrenes (Fig. 3) show also red-shifted absorption bands compared to pyrene and the low energy absorptions are very weak, with a somewhat larger optical gap than for the P-analogues, as usually observed for silole/oxophospholes. ${ }^{5}$ If we study the effect of the substitution pattern, absorption bands of $\mathbf{3 / 5}$, and in particular the $\mathrm{S}_{2} \leftarrow \mathrm{S}_{0}$ transition, are red-shifted compared to those of 6/7 indicating a higher extended $\pi$-conjugation for the bent compounds. These data show the high impact of the heteroatom nature and the substitution pattern on the absorption properties. All compounds display structured emission at lower energy compared to pyrene (Fig. 3 and Fig S3). All photoluminescence quantum yields are rather high (Table 1), unless for 7 . This low value remain unexplained. The emission spectrum of $\mathbf{3}$ exhibits sharp, well-resolved emission in hexane with an average vibrational spacing between the most prominent bands of $c a .1250 \mathrm{~cm}^{-1}$. These vibrational modes are characteristic for pure $\pi-\pi^{*}$ states in emission. ${ }^{3 \mathrm{j}}$ As observed for the absorption spectrum, the emission spectrum recorded in DCM for 3 is shifted up to $840 \mathrm{~cm}^{-1}$ compared to the absorption band in hexane showing that the excited state is more polar than the ground state. In solution, no excimeric emission was observed, even in saturated hexane solution $\left(c=10^{-4} \mathrm{M}\right)$, the corresponding spectra remain identical with increasing concentrations. This is rather surprising as pyrene has tendency to form excimers in nonpolar solvents even in diluted solutions. ${ }^{8}$ The presence of the tetrahedral heteroatoms probably induced enough steric hindrance to prevent the formation of excimers even in apolar solvent. The optical properties of $\mathbf{3}$ were also studied in the solid-state. The UVVis absorption in thin film (Fig. S2) showed a broadening of the bands accompanied by a red-shift of the edge of absorption. This indicates some interactions between the compounds in the ground state (as observed in the crystal packing, Fig. 2). Interestingly, the emission of $\mathbf{3}$ in thin film (Fig. 3) showed a broad red-shifted emission $\left(\Delta \lambda_{\mathrm{em}}=2700 \mathrm{~cm}^{-1}\right)$. Similar effect was observed for some amino and cyano substituted pyrenes. ${ }^{3 \mathrm{~h}}$ This broad emission is likely to be assigned to aggregates that are formed exclusively in the solid-state due to the packing. 

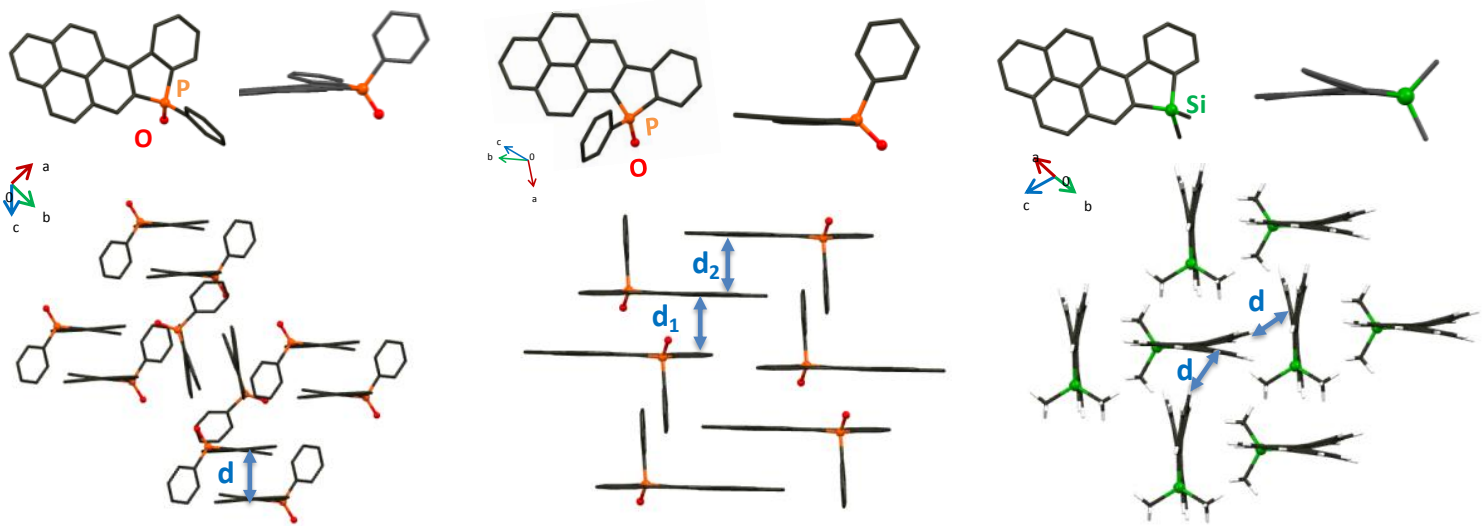

Figure 2. Crystallographic structure of $\mathbf{3}$ (left), $\mathbf{6}$ (middle), $\mathbf{5}$ (right) in top (up) and side view (middle) and view of the packing (down)
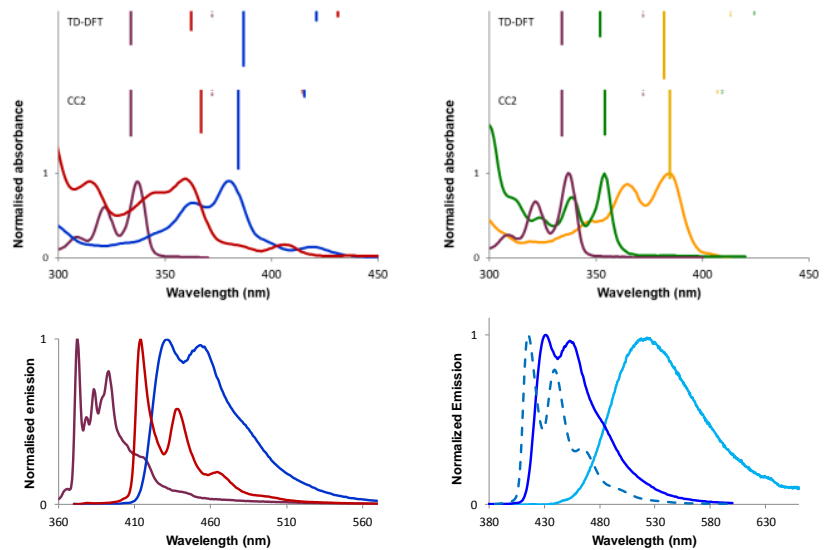

Figure 3. UV-vis absorption (top) of pyrene (purple), 3 (blue), 6 (red), 5 (yellow) and 7 (green). Fluorescence (bottom- left) in diluted DCM solution of pyrene (purple), 3 (blue), 6 (red). Emission spectra (bottom- right) of $\mathbf{3}$ measured in hexane (dotted line), DCM (dark blue) and in thin film (light blue). The calculated (for details see SI) vertical transition energies for the absorption spectrum are indicated above the spectra as vertical lines, their length indicating the intensity.

Regarding the redox properties (Table 1), in the whole series, benzoheterocycle-fused pyrenes are easier to oxidize and reduce compared to pyrene measured in the same conditions, ${ }^{9}$ thus confirming the lower gap measured by optical method, in particular in case of $\mathbf{3}$ and $\mathbf{5}$. Furthermore, $\mathrm{P}=\mathrm{O}$-containing pyrenes display reversible reduction at relatively low potential (Table 1). This underlines that these compounds possess high electron affinity, especially compared to thiophene-fused pyrenes. ${ }^{4 a}$

The observed electrochemical behaviour is in accordance with the calculated orbital energies. The $\pi$-orbitals resemble to the pyrene MOs (Fig. 4), but the geometry of the molecule strongly influences the orbitals' delocalization toward the heterocyclic unit. In case of linear molecules 6 and 7, both the HOMO and LUMO are localized mostly on the pyrene skeleton with a nodal surface at 2,7-position of pyrene. In case of 3 and 5 , the geometry allows further delocalization of these orbitals, resulting in the reduction of the HOMO-LUMO gap (causing a red shift on the ${ }^{1} \mathrm{~L}_{\mathrm{a}}$ band), in accordance with the results obtained from the optical end electrochemical measurements.
Table 1: Optical and electrochemical data

$\begin{array}{cccccc} & \lambda_{\text {abs }}(\log \varepsilon)^{\mathrm{a}} & \lambda_{\text {em }}{ }^{\mathrm{a}} & \phi^{\mathrm{b}} & \mathrm{E}_{\mathrm{ox}}{ }^{\mathrm{c}} & \mathrm{E}_{\text {red }}{ }^{\mathrm{c}} \\ & (\mathrm{nm}) & (\mathrm{nm}) & (\%) & (\mathrm{V}) & (\mathrm{V}) \\ \mathbf{3} & 420(4.06), 395(4.32), & 434 & 54 & 0.93^{\mathrm{d}} & -2.13^{\mathrm{d}} \\ & 383(4.91), 361(4.76) & & & & \\ \mathbf{5} & 404(2.89), 385(4.26) & 408 & 47 & 0.72^{\mathrm{d}} & -2.41^{\mathrm{d}} \\ & 364(3.91), 348(3.90) \\ \mathbf{6} & 414(3.33), 403(3.00), & 414 & 30 & 1.03 & -2.10^{\mathrm{d}} \\ & 390(3.29), 369(4.04) & & & & \\ \mathbf{7} & 354(4.44) ; 338(4.29) & 406 & 4 & 0.93 & -2.48 \\ & 324(4.11) & & & & \end{array}$

${ }^{\text {a In }} \mathrm{CH}_{2} \mathrm{Cl}_{2}\left(10^{-5} \mathrm{M}\right){ }^{\mathrm{b}}$ Measured relative to quinine sulfate $\left(\mathrm{H}_{2} \mathrm{SO}_{4}, 0.1 \mathrm{M}\right), \phi_{\mathrm{ref}}=0.55^{\mathrm{c}}$ In $\mathrm{CH}_{2} \mathrm{Cl}_{2}$ with $\mathrm{Bu}_{4} \mathrm{~N}^{+} \mathrm{PF}_{6}{ }^{-}(0.2 \mathrm{M})$ at a scan rate of $100 \mathrm{mVs}^{-1}$. $\mathrm{E}^{\text {ox }}\left(\mathrm{E}^{\mathrm{red}}\right)=1 / 2\left(\mathrm{E}_{\mathrm{pc}}+\mathrm{E}_{\mathrm{pa}}\right)$ for reversible or quasi-reversible process, otherwise $E^{o x}\left(E^{\text {red }}\right)=\left(E_{p a}\right)$. Potentials vs ferrocene/ferrocenium. ${ }^{\mathrm{d}}$ reversible process.

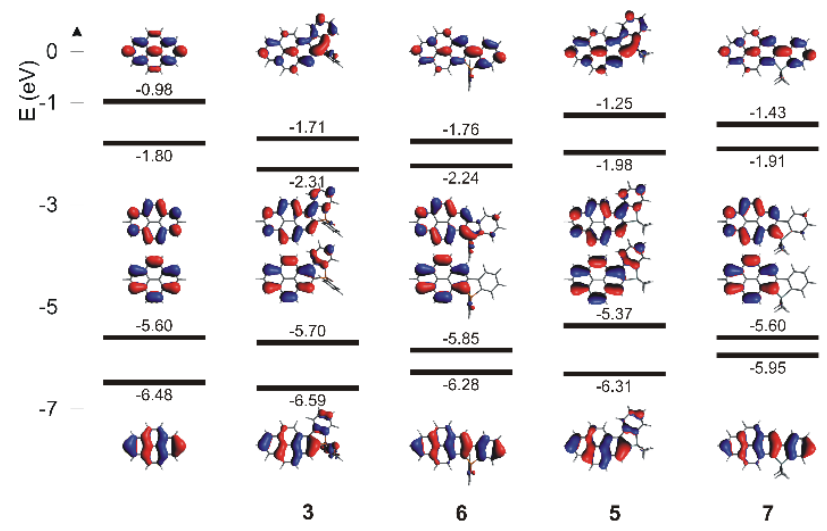

Figure 4. Molecular Orbitals (HOMO-1, HOMO, LUMO, LUMO +1 ) of pyrene, $\mathbf{3}, \mathbf{6}, \mathbf{5}$ and 7 at the B3LYP/6-31+G* level.

Interestingly, the $\mathrm{H}-\mathrm{H}$ repulsion induced non-planarity in case of the bent $\mathbf{3}$ and $\mathbf{5}$ has only a small effect on the shift of the HOMO and LUMO energies. While the FMO-s are more influenced by the substitution in case of $\mathbf{3}$ than in case of the linear $\mathbf{6}$, both geometric shapes allow the delocalization of the HOMO-1 and LUMO+1 orbitals. The changes in the orbital energies explain that the high intensity ${ }^{1} \mathrm{~L}_{\mathrm{a}}$ band (HOMO-LUMO transition) shows a larger red 
shift than the Lb band in case of the bent 3. Using both CC2 and TD DFT calculations, and appropriate corrections based on the measured data of the parent pyrene (for details see the SI) the band maxima of the absorption spectra can be well assigned (Fig. 3) as vertical excitation energies, with the exception of the low intensity ${ }^{1} \mathrm{~L}_{b}$ bands in the TD DFT calculation of the linear systems 6 .

The NICS(1) aromaticity investigation (Fig. 5) of the molecules revealed that the heteroles keep their usual aromatic properties (slightly antiaromatic for phosphole-oxide and non-aromatic for silole), as previously observed in P-containing PAHs ${ }^{5 e}$ The substitution doesn't have a strong effect on the aromaticity of the pyrene part, in accordance with the conclusion drawn from the investigation of the MO-s.

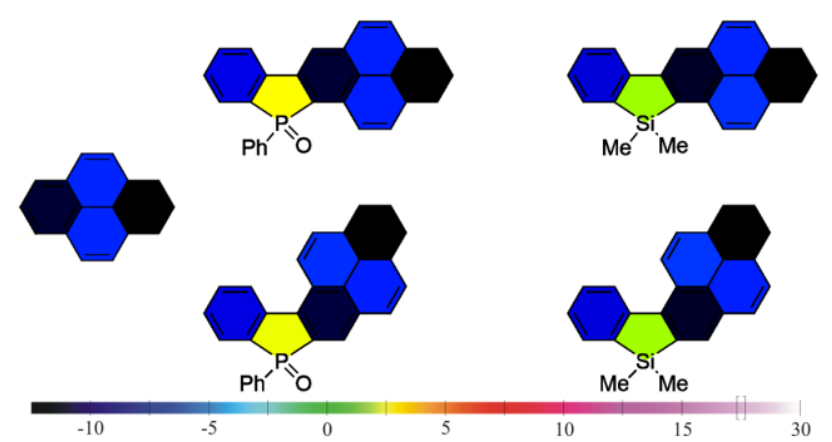

Figure 5. NICS(1) aromaticity patterns of pyrene, 3, 5-7 at the B3LYP/6-31+G* level.

We described the synthesis of novel pyrene-fused benzo[b]heterocyles containing $\mathrm{P}$ and $\mathrm{Si}$ using transition metal-catalysed $\mathrm{C}-\mathrm{H}$ bond activation. The compounds were fully characterized including $\mathrm{X}$-ray diffraction. The effect of the heteroatom and the substitution pattern on the optical and redox properties was studied experimentally and theoretically. This study opens the way toward the preparation of novel heteroatom containing $\mathrm{PAH}$ structures with potential applications in optoelectronic devices. ${ }^{10}$

\section{EXPERIMENTAL SECTION}

All experiments were performed under an atmosphere of dry argon using standard Schlenk techniques. Commercially available reagents were used as received without further purification. Solvents were freshly purified using MBRAUN SPS-800 drying columns. Separations were performed by gravity column chromatography on basic alumina (Aldrich, Type 5016A, 150 mesh, $58 \AA$ ) or silica gel (Merck Geduran 60, 0.063-0.200 mm). ${ }^{1} \mathrm{H},{ }^{13} \mathrm{C}$, and ${ }^{31} \mathrm{P}$ NMR spectra were recorded on Bruker AV III 300 and $400 \mathrm{MHz}$ NMR spectrometers equiped with $\mathrm{BBO}$ or $\mathrm{BBFO}$ probeheads. Assignment of proton and carbon atoms is based on COSY, NOESY, edited-HSQC and HMBC experiments. For products 3 and $\mathbf{6}$, special ${ }^{31} \mathrm{P}$ decoupled experiments $\left(\left\{{ }^{31} \mathrm{P}\right\}{ }^{1} \mathrm{H}\right.$, $\left\{{ }^{31} \mathrm{P}-{ }^{1} \mathrm{H}\right\}{ }^{13} \mathrm{C},\left\{{ }^{31} \mathrm{P}\right\}$-HSQC or HMBC) were performed on a Bruker Av III HD $500 \mathrm{MHz}$ fitted with a triple inverse probehead $\left({ }^{1} \mathrm{H}-{ }^{31} \mathrm{P}-\right.$ $\mathrm{X})$. These ${ }^{31} \mathrm{P}$ decoupled experiments have been performed using the PRISM core facility (Biogenouest $\odot$, UMS Biosit, Université de Rennes 1- Campus de Villejean- 35043 RENNES Cedex, FRANCE). ${ }^{1} \mathrm{H}$ and ${ }^{13} \mathrm{C}$ NMR chemical shifts were reported in parts per million (ppm) using residual solvent signal as reference. In the NMR description, $\mathrm{C}_{\mathrm{q}}$ corresponds to quaternary carbon; ipso, ortho, meta, para correspond to the respective positions on the exocyclic $\mathrm{P}-\mathrm{Ph} ; \alpha$ and $\beta$ to the position 2 and 3 of the heterole ring. High- resolution mass spectra were obtained on a Varian MAT 311 or ZabSpec TOF Micromass instrument at Scanmat (UMS 2001). UVVisible spectra were recorded at room temperature on a VARIAN Cary 5000 spectrophotometer. The UV-Vis emission and excitation spectra measurements were recorded on a FL 920 Edimburgh Instrument equipped with a Hamamatsu R5509-73 photomultiplier for the NIR domain (300-1700 nm) and corrected for the response of the photomultiplier. Quantum yields were calculated relative to quinine sulfate $\left(\mathrm{H}_{2} \mathrm{SO}_{4}, 0.1 \mathrm{M}\right)$, $\left.\phi_{\mathrm{ref}}=0.55\right)$. The electrochemical studies were carried out under argon using an Eco Chemie Autolab PGSTAT 30 potentiostat for cyclic voltammetry with the threeelectrode configuration: the working electrode was a platinum disk, the reference electrode was a saturated calomel electrode and the counter-electrode a platinum wire. All potential were internally referenced to the ferrocene/ ferrocenium couple. For the measurements, concentrations of $10^{-3} \mathrm{M}$ of the electroactive species were used in freshly distilled and degassed dichloromethane and $0.2 \mathrm{M}$ tetrabutylammonium hexafluorophosphate. (2-bromophenyl)diphenylphosphine BDP, 1-(2-bromophenyl)pyrene, pyrene-2-boronic acid, 2-(2-bromophenyl)pyrene were prepared according to the literature. ${ }^{11}$

7-Phenylbenzo[b]phenaleno[1,9-ef]phosphindole 7-oxide (3). pyrene-1-boronic acid (0.05 g, $0.20 \mathrm{mmol})$, (2-bromophenyl) diphenylphosphine BDP (0.08 g, $0.22 \mathrm{mmol})$ and potassium phosphate $(0.13 \mathrm{~g}, 0.60 \mathrm{mmol})$ were dissolved in DMF $(4 \mathrm{~mL})$. The solution was degassed and 1,1'-Bis (diphenylphosphino)ferrocene]dichloropalladium(II) (0.05 eq.) was added to the reaction mixture and was heated four days at $135^{\circ} \mathrm{C}$. The product dissolved in DCM and extracted with water. The organic layer was dried on $\mathrm{MgSO}_{4}$, filtrated and then the solvent was evaporated. The crude mixture was filtrated on dry Celite ${ }^{\circledR}$ pad with dry DCM to give the $\sigma^{3}, \lambda^{3} \mathrm{P}$ intermediate $2\left({ }^{31} \mathrm{P}\right.$ NMR $\left(161.99 \mathrm{MHz}, \mathrm{CD}_{2} \mathrm{Cl}_{2}\right)$ : $\delta(\mathrm{ppm})=-14.4$ (s), HR-MS (MS (ESI, $\mathrm{CH}_{3} \mathrm{OH} / \mathrm{CH}_{2} \mathrm{Cl}_{2}: 95 / 5, \mathrm{~m} / \mathrm{z}$ ): $[\mathrm{M}]^{+}$calc for $\mathrm{C}_{34} \mathrm{H}_{24} \mathrm{P}$ : 463.1616; found: 463.1617$)$ as a yellow solid (0.04 g, 41 $\%$ yield). The compound was dissolved in toluene $(0.60 \mathrm{~mL})$ and the mixture was degassed before adding palladium acetate $(0.05$ eq.). The reaction was stirred $12 \mathrm{~h}$ at $160{ }^{\circ} \mathrm{C}$ and then after cooling to room temperature, a $\mathrm{H}_{2} \mathrm{O}_{2} 30 \%$ solution ( $1 \mathrm{~mL}$ ) was added. The product was extraction with DCM, the organic layer was washed with water and then dried over $\mathrm{MgSO}_{4}$, filtrated and the solvent evaporated. The crude mixture was purified by silica gel chromatography using ethyl acetate/heptane $9 / 1$ as eluent to afford 3 as a yellow solid (0.05 g, 45\% yield). ${ }^{1} \mathrm{H}$ NMR (500.15 $\mathrm{MHz}$, $\left.\mathrm{CD}_{2} \mathrm{Cl}_{2}\right): \delta 7.39\left(\mathrm{ddt},{ }^{3} J(\mathrm{H}-\mathrm{H})=7.5 \mathrm{~Hz},{ }^{3} J(\mathrm{H}-\mathrm{H})=4.7,{ }^{4} J(\mathrm{H}-\mathrm{H})=\right.$ $\left.2.3 \mathrm{~Hz}, 2 \mathrm{H}, \mathrm{CH}_{\text {ortho }}\right)$; 7.46-7.48 (m, 1H); 7.48-7.51 (m, 1H, $\left.\mathrm{CH}_{\text {para }}\right)$; 7.68-7.73 (m, 2H, CHmeta); 7.69-7.76 (m, 1H); 7.84-7.87 (ddd, $\left.{ }^{3} J(\mathrm{H}-\mathrm{H})=10.5 \mathrm{~Hz}, J(\mathrm{H}-\mathrm{P})=7.2 \mathrm{~Hz},{ }^{5} J(\mathrm{H}-\mathrm{H})=0.6 \mathrm{~Hz}, 1 \mathrm{H}\right) ; 7.98$ $\left(\mathrm{d},{ }^{3} \mathrm{~J}(\mathrm{H}-\mathrm{H})=8.8 \mathrm{~Hz}, 1 \mathrm{H}\right) ; 8.02\left(\mathrm{t},{ }^{3} \mathrm{~J}(\mathrm{H}-\mathrm{H})=7.6 \mathrm{~Hz}, 1 \mathrm{H}\right) ; 8.04(\mathrm{~d}$, $\left.{ }^{3} J(\mathrm{H}-\mathrm{H})=8.8 \mathrm{~Hz}, 1 \mathrm{H}\right) ; 8.17\left(\mathrm{~d},{ }^{3} J(\mathrm{H}-\mathrm{H})=7.6 \mathrm{~Hz}, 1 \mathrm{H}\right) ; 8.18(\mathrm{~d}$, $\left.{ }^{3} J(\mathrm{H}-\mathrm{H})=7.3 \mathrm{~Hz}, 1 \mathrm{H}\right) ; 8.19\left(\mathrm{~d},{ }^{3} J(\mathrm{H}-\mathrm{H})=9.4 \mathrm{~Hz}, 1 \mathrm{H}\right) ; 8.43(\mathrm{~d}$, $\left.{ }^{3} J(\mathrm{H}-\mathrm{H})=10.8 \mathrm{~Hz}, 1 \mathrm{H}\right) ; 8.63\left(\mathrm{dd},{ }^{3} J(\mathrm{H}-\mathrm{H})=8.1 \mathrm{~Hz},{ }^{4} J=3.5 \mathrm{~Hz}\right.$, $1 \mathrm{H}) ; 8.93\left(\mathrm{~d},{ }^{3} \mathrm{~J}(\mathrm{H}-\mathrm{H})=9.4 \mathrm{~Hz}, 1 \mathrm{H}\right) .{ }^{13} \mathrm{C}\left\{{ }^{1} \mathrm{H}\right\} \mathrm{NMR}(125.78 \mathrm{MHz}$, $\mathrm{CD}_{2} \mathrm{Cl}_{2}$ ): $\delta 123.7(\mathrm{~s}, \mathrm{CH}) ; 125.2\left(\mathrm{~s}, C_{q}\right) ; 126.1\left(\mathrm{~d},{ }^{3} J(\mathrm{C}-\mathrm{P})=9.8 \mathrm{~Hz}\right.$, $\mathrm{CH}) ; 126.4(\mathrm{~s}, \mathrm{CH}) ; 126.5\left(\mathrm{~d},{ }^{3} \mathrm{~J}(\mathrm{C}-\mathrm{P})=10.4 \mathrm{~Hz}, \mathrm{CH}\right) ; 127.0(\mathrm{~s}$, $\mathrm{CH}) ; 127.6(\mathrm{~s}, \mathrm{CH}) ; 128.0$ (d, $\left.{ }^{3} J(\mathrm{C}-\mathrm{P})=10.4 \mathrm{~Hz}, \mathrm{Cq}\right) ; 128.1(\mathrm{~s}$, $\mathrm{CH}) ; 128.5\left(\mathrm{~d},{ }^{5} \mathrm{~J}(\mathrm{C}-\mathrm{P})=1.8 \mathrm{~Hz}, C_{q}\right) ; 129.1(\mathrm{~s}, \mathrm{CH}) ; 129.3\left(\mathrm{~d},{ }^{2} \mathrm{~J}(\mathrm{C}-\right.$ 
$\left.\mathrm{P})=12.5 \mathrm{~Hz}, C \mathrm{H}_{\text {meta }}\right) ; 129.4\left(\mathrm{~d},{ }^{2} J(\mathrm{C}-\mathrm{P})=11.1 \mathrm{~Hz}, \mathrm{CH}\right) ; 130.0(\mathrm{~s}$, $\mathrm{CH}) ; 130.8\left(\mathrm{~d},{ }^{3} \mathrm{~J}(\mathrm{C}-\mathrm{P})=9.2 \mathrm{~Hz}, \mathrm{CH}\right) ; 131.4\left(\mathrm{~s}, \mathrm{C}_{q}\right) ; 131.7\left(\mathrm{~d},{ }^{2} J(\mathrm{C}-\right.$ $\left.\mathrm{P})=10.8 \mathrm{~Hz}, C \mathrm{H}_{\text {ortho }}\right) ; 132.2\left(\mathrm{~d},{ }^{1} J(\mathrm{C}-\mathrm{P})=103.4 \mathrm{~Hz}, C_{\text {ipso }}\right) ; 132.4$ $\left(\mathrm{d},{ }^{2} J=11.9 \mathrm{~Hz}, \mathrm{C}_{\mathrm{q}}\right) ; 132.6\left(\mathrm{~d},{ }^{4} J(\mathrm{C}-\mathrm{P})=2.9 \mathrm{~Hz}, C_{\text {para }}\right) ; 132.7(\mathrm{~d}$, $\left.{ }^{I} J(\mathrm{C}-\mathrm{P})=104.5 \mathrm{~Hz}, C_{\alpha}\right) ; 134.1\left(\mathrm{~d},{ }^{4} J(\mathrm{C}-\mathrm{P})=2.1 \mathrm{~Hz}, C H\right) ; 134.5(\mathrm{~d}$, $\left.{ }^{2} J(\mathrm{C}-\mathrm{P})=21.6 \mathrm{~Hz}, C_{\beta}\right) ; 135.4\left(\mathrm{~d},{ }^{1} J(\mathrm{C}-\mathrm{P})=104.1 \mathrm{~Hz}, C_{\alpha}\right) ; 144.4$ $\left(\mathrm{d},{ }^{2} J(\mathrm{C}-\mathrm{P})=21.2 \mathrm{~Hz}, C_{\beta}\right) .1 \mathrm{Cq}$ is not observed. ${ }^{31} \mathrm{P} \mathrm{NMR}\left\{{ }^{1} \mathrm{H}\right\}$ $\left(161.99 \mathrm{MHz}, \quad \mathrm{CD}_{2} \mathrm{Cl}_{2}\right): \delta+30.7$ (s). HR-MS (ESI, $\mathrm{CH}_{3} \mathrm{OH} / \mathrm{CH}_{2} \mathrm{Cl}_{2}$ : 70/30: $\mathrm{m} / \mathrm{z}$ ): $[\mathrm{M}+\mathrm{Na}]^{+}$calcd for $\mathrm{C}_{28} \mathrm{H}_{17} \mathrm{ONaP}$ : 423.0915; found 423.0909 .

Dimethyl(2-(pyren-1-yl)phenyl)silane (4). 1-(2-bromophenyl)pyrene $(0.10 \mathrm{~g}, 0.28 \mathrm{mmol})$ was dissolved in $6 \mathrm{~mL}$ of distilled THF and cooled down at $-78^{\circ} \mathrm{C}$ before adding $n \mathrm{BuLi}(0.15$ $\mathrm{mL}, 0.36 \mathrm{mmol}, \mathrm{M}=2.4 \mathrm{~mol} / \mathrm{L})$. After $1 \mathrm{~h}$ of stirring at $-78^{\circ} \mathrm{C}$, the temperature was cooled down to $-110^{\circ} \mathrm{C}$ and chlorodimethylsilane $(0.09 \mathrm{~mL}, 0.84 \mathrm{mmol})$ was added. The reaction mixture was stirred overnight at room temperature followed by dissolution in DCM and extraction with water. The organic layer was dried on $\mathrm{MgSO}_{4}$, filtrated and then the solvent evaporated. The crude mixture was purified by silica gel chromatography using pentane as eluent to afford 4 as colourless solid (0.09 g, $88 \%$ yield). ${ }^{1} \mathrm{H}$ NMR (400.16 $\left.\mathrm{MHz}, \mathrm{CD}_{2} \mathrm{Cl}_{2}\right): \delta-0.07\left(\mathrm{~d},{ }^{3} \mathrm{~J}(\mathrm{H}-\mathrm{H})=3.8 \mathrm{~Hz}, 6 \mathrm{H}, \mathrm{SiMe}_{2}\right) ; 4.05$ (hept, $\left.{ }^{3} J(\mathrm{H}-\mathrm{H})=3.8 \mathrm{~Hz}, 1 \mathrm{H}, \mathrm{Si}-H\right) ; 7.48-7.50(\mathrm{~m}, 1 \mathrm{H}) ; 7.58(\mathrm{td}$, $\left.{ }^{3} J(\mathrm{H}-\mathrm{H})=7.5 \mathrm{~Hz},{ }^{4} J(\mathrm{H}-\mathrm{H})=1.9 \mathrm{~Hz}, 1 \mathrm{H}\right) ; 7.61\left(\mathrm{td},{ }^{3} J(\mathrm{H}-\mathrm{H})=7.4\right.$ $\left.\mathrm{Hz},{ }^{4} J(\mathrm{H}-\mathrm{H})=2.0 \mathrm{~Hz}, 1 \mathrm{H}\right) ; 7.82\left(\mathrm{~d},{ }^{3} J(\mathrm{H}-\mathrm{H})=9.2 \mathrm{~Hz}, 1 \mathrm{H}\right) ; 7.85-$ $7.88(\mathrm{~m}, 1 \mathrm{H}) ; 8.01\left(\mathrm{~d},{ }^{3} J(\mathrm{H}-\mathrm{H})=7.8 \mathrm{~Hz}, 1 \mathrm{H}\right) ; 8.05\left(\mathrm{~d},{ }^{3} J(\mathrm{H}-\mathrm{H})=\right.$ $9.0 \mathrm{~Hz}, 1 \mathrm{H}) ; 8.08(\mathrm{~d}, J(\mathrm{H}-\mathrm{H})=8 \mathrm{~Hz}, 1 \mathrm{H}) ; 8.18\left(\mathrm{~d},{ }^{3} J(\mathrm{H}-\mathrm{H})=9.1\right.$ $\mathrm{Hz}, 1 \mathrm{H}) ; 8.20\left(\mathrm{~d},{ }^{3} J(\mathrm{H}-\mathrm{H})=9.1,1 \mathrm{H}\right) ; 8.22-8.25(\mathrm{~m}, 1 \mathrm{H}) ; 8.28(\mathrm{~d}$, $\left.{ }^{3} J(\mathrm{H}-\mathrm{H})=7.6 \mathrm{~Hz}, 1 \mathrm{H}\right) ; 8.29\left(\mathrm{~d},{ }^{3} J(\mathrm{H}-\mathrm{H})=7.8 \mathrm{~Hz}, 1 \mathrm{H}\right) .{ }^{13} \mathrm{C} \mathrm{NMR}$ $\left\{{ }^{1} \mathrm{H}\right\}\left(100.62 \mathrm{MHz}, \mathrm{CD}_{2} \mathrm{Cl}_{2}\right): \delta-3.4\left(\mathrm{~d},{ }^{l} \mathrm{~J}(\mathrm{C}-\mathrm{Si})=10.0 \mathrm{~Hz}, \mathrm{CH}_{3}\right)$; 124.0 (s, $C H$ ); 124.5 (s, $\left.C_{q}\right) ; 124.7$ (s, $\left.C_{q}\right) ; 125.0$ (s, $\left.C H\right) ; 125.2$ (s, $\mathrm{CH}) ; 125.8$ (s, $\mathrm{CH}) ; 126.1$ (s, $\mathrm{CH}) ; 126.8$ (s, $\mathrm{CH}) ; 127.2$ (s, $\mathrm{CH})$; 127.4 (s, $\mathrm{CH}) ; 127.5$ (s, $\mathrm{CH}) ; 128.0(\mathrm{~s}, \mathrm{CH}) ; 128.9$ (s, $\mathrm{CH}) ; 129.6$ $\left(\mathrm{s}, C_{q}\right) ; 130.5(\mathrm{~s}, C H) ; 130.8\left(\mathrm{~s}, C_{q}\right) ; 131.0\left(\mathrm{~s}, C_{q}\right) ; 131.5\left(\mathrm{~s}, C_{q}\right)$; 135.0 (s, $C H) ; 137.7$ (s, $\left.C_{q}\right) ; 138.7\left(\mathrm{~s}, C_{q}\right) ; 147.5$ (s, $\left.C_{q}\right)$. HR-MS (ESI, $\mathrm{CH}_{3} \mathrm{OH} / \mathrm{CH}_{2} \mathrm{Cl}_{2}: 70 / 30, \mathrm{~m} / \mathrm{z}$ ): $[\mathrm{M}+\mathrm{Na}]^{+}$calcd for $\mathrm{C}_{24} \mathrm{H}_{20} \mathrm{NaSi}$ : 359.1232; found: 359.1226 .

7,7-Dimethyl-7H-benzo[b]pyreno[1,2-d]silole (5). A mixture of 4 $(0.53 \mathrm{~g}, 1.57 \mathrm{mmol})$ and 1,4-dioxane $(2 \mathrm{~mL})$ was degassed, then tris(triphenylphosphine)rhodium(I) chloride $(0.07 \mathrm{~g}, 0.08 \mathrm{mmol})$ was added and stirred at $135{ }^{\circ} \mathrm{C}$ overnight. The resulting dark brown mixture was dissolved in DCM and the organic phase washed with water. The organic layer was dried on $\mathrm{MgSO}_{4}$, then the solvent evaporated and the crude mixture was purified by silica gel chromatography (pentane/ethyl acetate, 98/2), by neutral alumina chromatography (pentane) and by preparative TLC (pentane/ethyl acetate, 98/2) to afford $\mathbf{5}$ as a yellowish solid $(0.12 \mathrm{~g}$, $23 \%$ yield). ${ }^{1} \mathrm{H}$ NMR (400.16 MHz, $\left.\mathrm{CD}_{2} \mathrm{Cl}_{2}\right): \delta 0.60(\mathrm{~s}, 6 \mathrm{H}$, $\left.\mathrm{SiMe}_{2}\right) ; 7.40-7.44(\mathrm{~m}, 1 \mathrm{H}) ; 7.60-7.65(\mathrm{~m}, 1 \mathrm{H}) ; 7.86\left(\mathrm{ddd},{ }^{3} J(\mathrm{H}-\mathrm{H})=\right.$ $\left.7.0 \mathrm{~Hz},{ }^{4} J(\mathrm{H}-\mathrm{H})=1.5 \mathrm{~Hz},{ }^{5} J(\mathrm{H}-\mathrm{H})=0.7 \mathrm{~Hz}, 1 \mathrm{H}\right) ; 8.06\left(\mathrm{dd},{ }^{3} J(\mathrm{H}-\right.$ $\left.\mathrm{H})=7.2 \mathrm{~Hz},{ }^{4} J(\mathrm{H}-\mathrm{H})=4.0 \mathrm{~Hz}, 1 \mathrm{H}\right) ; 8.10-8.16(\mathrm{~m}, 2 \mathrm{H}) ; 8.20-8.25$ $(\mathrm{m}, 3 \mathrm{H}) ; 8.49(\mathrm{~s}, 1 \mathrm{H}) ; 8.63\left(\mathrm{dd},{ }^{3} J(\mathrm{H}-\mathrm{H})=8.1 \mathrm{~Hz},{ }^{5} J(\mathrm{H}-\mathrm{H})=0.8\right.$ $\mathrm{Hz}, 1 \mathrm{H}) ; 9.12\left(\mathrm{~d},{ }^{3} J(\mathrm{H}-\mathrm{H})=9.5 \mathrm{~Hz}, 1 \mathrm{H}\right) .{ }^{13} \mathrm{C} \mathrm{NMR}\left\{{ }^{1} \mathrm{H}\right\}(100.62$ $\left.\mathrm{MHz}, \mathrm{CD}_{2} \mathrm{Cl}_{2}\right): \delta-3.3\left(\mathrm{~s}, \mathrm{CH}_{3}\right) ; 124.3(\mathrm{~s}, \mathrm{CH}) ; 124.7$ (s, $\left.\mathrm{CH}\right) ; 125.3$ $(\mathrm{s}, C \mathrm{H}) ; 126.1(\mathrm{~s}, C \mathrm{H}) ; 126.4(\mathrm{~s}, C \mathrm{H}) ; 126.5\left(\mathrm{~s}, \mathrm{C}_{\mathrm{q}}\right) ; 126.6\left(\mathrm{~s}, \mathrm{C}_{\mathrm{q}}\right)$; $126.9(\mathrm{~s}, C \mathrm{H}) ; 127.2(\mathrm{~s}, C \mathrm{H}) ; 127.5(\mathrm{~s}, C \mathrm{H}) ; 127.7(\mathrm{~s}, C \mathrm{H}) ; 129.1$ $(\mathrm{s}, C \mathrm{H}) ; 130.1(\mathrm{~s}, C \mathrm{H}) ; 130.3\left(\mathrm{~s}, C_{q}\right) ; 130.9\left(\mathrm{~s}, C_{q}\right) ; 131.8\left(\mathrm{~s}, C_{q}\right)$;
133.3 (s, $C \mathrm{H}) ; 138.8$ (s, $C_{\alpha}$ ); 141.3 (s, $\left.C_{\alpha}\right) ; 141.7$ (s, $\left.C_{\beta}\right) ; 149.7$ (s, $C_{\beta}$ ). $1 \mathrm{Cq}$ is missing due to overlapping. HR-MS (ESI, $\mathrm{CH}_{3} \mathrm{OH} / \mathrm{CH}_{2} \mathrm{Cl}_{2}$ : $70 / 30, \mathrm{~m} / \mathrm{z}$ ): $[\mathrm{M}+\mathrm{Na}]^{+}$calcd for $\mathrm{C}_{24} \mathrm{H}_{18} \mathrm{NaSi}$ : 357.1076; found: 357.1070 .

11-Phenylbenzo[b]phenaleno[1,9-fg]phosphindole 11-oxide (6). Pyrene-2-boronic acid (0.05 g, $0.20 \mathrm{mmol})$, (2-bromophenyl) diphenylphosphine $(0.08 \mathrm{~g}, 0.22 \mathrm{mmol})$ and potassium phosphate $(0.13 \mathrm{~g}, 0.60 \mathrm{mmol})$ were dissolved in DMF (4 mL). The solution was degassed and [1,1'-Bis(diphenylphosphino) ferrocene] dichloropalladium (II) (0.05 eq.) was added to the reaction mixture and heated three days at $135^{\circ} \mathrm{C}$. The solution was then extracted with DCM. The organic layer was dried on $\mathrm{MgSO}_{4}$, filtrated and then the solvent was evaporated. The crude mixture was filtrated on Celite ${ }^{\circledR}$ with dry DCM to give to give the $\sigma^{3}, \lambda^{3} \mathrm{P}$ intermediate $\left({ }^{31} \mathrm{P}\right.$ $\left.\operatorname{NMR}\left(161.99 \mathrm{MHz}, \mathrm{CD}_{2} \mathrm{Cl}_{2}\right): \delta(\mathrm{ppm})=-13.5(\mathrm{~s})\right)$ as a yellow solid $(0.03 \mathrm{~g}, 33 \%$ yield). The crude was dissolved in toluene $(0.6 \mathrm{~mL})$ and the mixture was degassed before adding palladium acetate ( 0.05 eq.). The reaction was stirred $12 \mathrm{~h}$ at $160{ }^{\circ} \mathrm{C}$, then after cooling, a $30 \%$ aqueous $\mathrm{H}_{2} \mathrm{O}_{2}$ solution ( $1 \mathrm{~mL}$ ) was added for oxidation followed by dissolution in DCM and extraction with water. The organic layer was dried on $\mathrm{MgSO}_{4}$, filtrated and then the solvent was evaporated. The crude mixture was purified by silica gel chromatography using ethyl acetate/heptane, $9 / 1$ as eluent to afford $\mathbf{6}$ as a yellow solid (0.03 g, 25\% yield). ${ }^{1} \mathrm{H}$ NMR (500.15 $\left.\mathrm{MHz}, \mathrm{CD}_{2} \mathrm{Cl}_{2}\right)$ : $\delta 7.37\left(\mathrm{t},{ }^{3} J(\mathrm{H}-\mathrm{H})=7.6 \mathrm{~Hz}, 2 \mathrm{H}, H_{\text {metha }}\right) ; 7.47(\mathrm{t}, J(\mathrm{H}-\mathrm{H})=7.3 \mathrm{~Hz}$, $2 \mathrm{H}) ; 7.65-7.71(\mathrm{~m}, 1 \mathrm{H}) ; 7.72\left(\mathrm{~m}, 2 \mathrm{H}, H_{\text {ortho }}\right) ; 7.77-7.79(\mathrm{~m}, 1 \mathrm{H})$; $8.02\left(\mathrm{t},{ }^{3} J(\mathrm{H}-\mathrm{H})=7.6 \mathrm{~Hz}, 1 \mathrm{H}\right) ; 8.12\left(\mathrm{~d},{ }^{3} J(\mathrm{H}-\mathrm{H})=9.0 \mathrm{~Hz}, 1 \mathrm{H}\right) ; 8.16$ $\left(\mathrm{dd},{ }^{3} J(\mathrm{H}-\mathrm{H})=5.2 \mathrm{~Hz},{ }^{4} J(\mathrm{H}-\mathrm{H})=2.7 \mathrm{~Hz}, 1 \mathrm{H}\right) ; 8.19\left(\mathrm{~d},{ }^{3} J(\mathrm{H}-\mathrm{H})=\right.$ $5.9 \mathrm{~Hz}, 2 \mathrm{H}) ; 8.21(\mathrm{~d}, J(\mathrm{H}-\mathrm{H})=7.4 \mathrm{~Hz}, 1 \mathrm{H}) ; 8.24(\mathrm{~d}, J(\mathrm{H}-\mathrm{H})=8.0$ $\mathrm{Hz}, 1 \mathrm{H}) ; 8.35\left(\mathrm{~d},{ }^{3} \mathrm{~J}(\mathrm{H}-\mathrm{H})=9.0 \mathrm{~Hz}, 1 \mathrm{H}\right) ; 8.60(\mathrm{~s}, 1 \mathrm{H}) .{ }^{13} \mathrm{C}\left\{{ }^{1} \mathrm{H}\right\}$ NMR (125.78 MHz, $\left.\mathrm{CD}_{2} \mathrm{Cl}_{2}\right): \delta 117.6\left(\mathrm{~d},{ }^{3} J(\mathrm{C}-\mathrm{P})=10.6 \mathrm{~Hz}, \mathrm{CH}\right)$; $122.4\left(\mathrm{~d},{ }^{3} J(\mathrm{C}-\mathrm{P})=10.1 \mathrm{~Hz}, \mathrm{CH}\right) ; 124.9\left(\mathrm{~d},{ }^{4} J(\mathrm{C}-\mathrm{P})=5.9 \mathrm{~Hz}, \mathrm{CH}\right)$; $125.2(\mathrm{~d}, J(\mathrm{C}-\mathrm{P})=83.0 \mathrm{~Hz}, C \mathrm{q}) ; 126.0\left(\mathrm{~d},{ }^{l} J(\mathrm{C}-\mathrm{P})=97.1 \mathrm{~Hz}, C_{\alpha}\right)$; 127.1 (s, $\mathrm{CH}) ; 127.2$ (s, $\mathrm{CH}) ; 127.4(\mathrm{~s}, \mathrm{CH}) ; 128.0(\mathrm{~s}, \mathrm{CH}) ; 129.0$ $\left(\mathrm{d},{ }^{3} J=12.0 \mathrm{~Hz}, C_{q}\right) ; 129.3\left(\mathrm{~d},{ }^{2} J(\mathrm{C}-\mathrm{P})=12.4 \mathrm{~Hz}, C_{\text {meta }}\right) ; 130.1$ $\left(\mathrm{d},{ }^{3} J(\mathrm{C}-\mathrm{P})=9.8 \mathrm{~Hz}, \mathrm{CH}\right) ; 130.3\left(\mathrm{~d},{ }^{3} J(\mathrm{C}-\mathrm{P})=11.1 \mathrm{~Hz}, \mathrm{CH}_{\text {para }}\right)$; $130.6(\mathrm{~s}, \mathrm{CH}) ; 130.8(\mathrm{~s}, \mathrm{CH}) ; 131.2(\mathrm{~d}, J(\mathrm{C}-\mathrm{P})=49.1 \mathrm{~Hz}, \mathrm{Cq}) ; 131.6$ $\left(\mathrm{d},{ }^{3} J(\mathrm{C}-\mathrm{P})=10.8 \mathrm{~Hz}, C_{\text {ortho }}\right) ; 132.5\left(\mathrm{~d},{ }^{3} \mathrm{~J}=9.8 \mathrm{~Hz}, C_{q}\right) ; 132.6(\mathrm{~d}$, $\left.{ }^{l} J(\mathrm{C}-\mathrm{P})=102.3 \mathrm{~Hz}, C_{i p s o}\right) ; 132.6\left(\mathrm{~d},{ }^{4} J(\mathrm{C}-\mathrm{P})=2.8 \mathrm{~Hz}, C \mathrm{H}\right) ; 133.2$ $\left(\mathrm{d},{ }^{3} J(\mathrm{C}-\mathrm{P})=8.9 \mathrm{~Hz}, C_{q}\right) ; 134.0\left(\mathrm{~d},{ }^{4} J(\mathrm{C}-\mathrm{P})=2.1 \mathrm{~Hz}, \mathrm{CH}\right) ; 135.0$ $\left(\mathrm{d},{ }^{l} J(\mathrm{C}-\mathrm{P})=106.9 \mathrm{~Hz}, C_{\alpha}\right) ; 136.1\left(\mathrm{~d},{ }^{4} J(\mathrm{C}-\mathrm{P})=2.0 \mathrm{~Hz}, C_{q}\right) ; 140.1$ $\left(\mathrm{d},{ }^{2} J(\mathrm{C}-\mathrm{P})=21.4 \mathrm{~Hz}, C_{\beta}\right) ; 142.8\left(\mathrm{~d},{ }^{2} J(\mathrm{C}-\mathrm{P})=21.5 \mathrm{~Hz}, C_{\beta}\right) .{ }^{31} \mathrm{P}$ $\left\{{ }^{1} \mathrm{H}\right\}$ NMR (161.99 MHz, $\left.\mathrm{CD}_{2} \mathrm{Cl}_{2}\right): \delta+32.6$ (s). HR-MS (ESI, $\left.\mathrm{CH}_{3} \mathrm{OH} / \mathrm{CH}_{2} \mathrm{Cl}_{2}: 80 / 20, \mathrm{~m} / \mathrm{z}\right)[\mathrm{M}+\mathrm{Na}]^{+}$calcd for $\mathrm{C}_{28} \mathrm{H}_{17} \mathrm{ONaP}$ : 423.0915; found 423.0909.

11,11-Dimethyl-11H-benzo[b]pyreno[2,1-d]silole (7). 2-(2-bromophenyl)pyrene $(0.19 \mathrm{~g}, 0.55 \mathrm{mmol})$ was dissolved in distilled THF $(10 \mathrm{~mL})$, then the mixture was cooled down at $-78{ }^{\circ} \mathrm{C}$ before to add $n \mathrm{BuLi}(0.28 \mathrm{~mL}, 0.71 \mathrm{mmol}, \mathrm{M}=2.45 \mathrm{~mol} / \mathrm{L})$. After one hour at $-78^{\circ} \mathrm{C}$, chlorodimethylsilane $(0.18 \mathrm{~mL}, 1.65 \mathrm{mmol})$ was added. The reaction mixture was stirred overnight at room temperature, dissolved in DCM and extracted with water. The organic layer was dried on $\mathrm{MgSO}_{4}$, filtrated and then the solvent was evaporated. The crude mixture was purified by silica gel chromatography using pentane as eluent to afford $\mathbf{4 b}$ (see $\mathrm{SI}$ ) as yellow oil (0.06 g, 35\% yield). Intermediate $4 \mathbf{b}$ (HR-MS (ESI, 
$\left.\mathrm{CH}_{3} \mathrm{OH} / \mathrm{CH}_{2} \mathrm{Cl}_{2}: 70 / 30, \mathrm{~m} / \mathrm{z}\right):[\mathrm{M}+\mathrm{Na}]^{+}$calcd for $\mathrm{C}_{24} \mathrm{H}_{20} \mathrm{NaSi}$ : 359.1232; found: 359.1227$)$ has been engaged without further purification in the next step. $4 \mathbf{b}(0.18 \mathrm{~g}, 0.53 \mathrm{mmol})$ and 1,4-dioxane (1 $\mathrm{mL}$ ) was degassed, then tris(triphenylphosphine)rhodium(I) chloride $(0.03 \mathrm{~g}, 0.03 \mathrm{mmol})$ was added and the reaction mixture stirred at $135{ }^{\circ} \mathrm{C}$ overnight. The resulting dark brown mixture was extracted with DCM and the organic phase washed with water. The organic layer was dried on $\mathrm{MgSO}_{4}$, filtrated and then the solvent evaporated. The crude mixture was purified by silica gel chromatography (pentane/ethyl acetate, 98/2), then by neutral alumina chromatography (pentane) and finally by preparative TLC (pentane/ethyl acetate, 98/2) to afford 7 as a clear yellowish solid (0.02 g, $11 \%$ yield). ${ }^{1} \mathrm{H}$ NMR (400.16 MHz, $\left.\mathrm{CD}_{2} \mathrm{Cl}_{2}\right): \delta 0.74(\mathrm{~s}, 6 \mathrm{H}, \mathrm{Si}-$ $\left.(\mathrm{CH})_{2}\right) ; 7.42\left(\mathrm{td},{ }^{3} J(\mathrm{H}-\mathrm{H})=7.2 \mathrm{~Hz} ;{ }^{4} J(\mathrm{H}-\mathrm{H})=1.0 \mathrm{~Hz}, 1 \mathrm{H}\right) ; 7.60$ $\left(\mathrm{td},{ }^{3} J(\mathrm{H}-\mathrm{H})=7.4 \mathrm{~Hz},{ }^{4} J(\mathrm{H}-\mathrm{H})=1.3 \mathrm{~Hz}, 1 \mathrm{H}\right) ; 7.82\left(\mathrm{ddd},{ }^{3} J(\mathrm{H}-\mathrm{H})\right.$ $\left.=7.0 \mathrm{~Hz},{ }^{4} \mathrm{~J}(\mathrm{H}-\mathrm{H})=1.4 \mathrm{~Hz},{ }^{5} J(\mathrm{H}-\mathrm{H})=0.8 \mathrm{~Hz}, 1 \mathrm{H}\right) ; 8.04\left(\mathrm{t},{ }^{3} J(\mathrm{H}-\right.$ $\mathrm{H})=7.6 \mathrm{~Hz}, 1 \mathrm{H}) ; 8.14-8.20(\mathrm{~m}, 4 \mathrm{H}) ; 8.20-82.26(\mathrm{~m}, 3 \mathrm{H}) ; 8.68(\mathrm{~s}$, 1H). ${ }^{13} \mathrm{C} \mathrm{NMR}\left\{{ }^{1} \mathrm{H}\right\}\left(100.62 \mathrm{MHz}, \mathrm{CD}_{2} \mathrm{Cl}_{2}\right): \delta-2.8\left(\mathrm{~s}, \mathrm{CH}_{3}\right) ; 117.3$ $(\mathrm{s}, C \mathrm{H}) ; 121.4(\mathrm{~s}, C \mathrm{H}) ; 124.2\left(\mathrm{~s}, C_{q}\right) ; 125.0\left(\mathrm{~s}, C_{q}\right) ; 125.3(\mathrm{~s}, C \mathrm{H})$; $125.4(\mathrm{~s}, \mathrm{CH}) ; 125.8(\mathrm{~s}, \mathrm{CH}) ; 127.8(\mathrm{~s}, \mathrm{CH}) ; 127.9(\mathrm{~s}, \mathrm{CH}) ; 128.0$ $(\mathrm{s}, \mathrm{CH}) ; 128.1(\mathrm{~s}, \mathrm{CH}) ; 128.2(\mathrm{~s}, \mathrm{CH}) ; 130.4(\mathrm{~s}, \mathrm{CH}) ; 130.9\left(\mathrm{~s}, C_{q}\right)$; $131.2\left(\mathrm{~s}, C_{q}\right) ; 132.9(\mathrm{~s}, C \mathrm{H}) ; 133.4\left(\mathrm{~s}, C_{q}\right) ; 135.3\left(\mathrm{~s}, C_{\alpha}\right) ; 135.6(\mathrm{~s}$, $\left.C_{q}\right) ; 139.6\left(\mathrm{~s}, C_{\alpha}\right) ; 145.9\left(\mathrm{~s}, C_{\beta}\right) ; 148.2\left(\mathrm{~s}, C_{\beta}\right)$. HR-MS (ASAP, 150 $\left.{ }^{\circ} \mathrm{C}\right)$ : $\mathrm{M}^{+}$. calcd for $\mathrm{C}_{24} \mathrm{H}_{18} \mathrm{Si}$ : 334.1178 ; found: 334.1172 .

\section{ASSOCIATED CONTENT Supporting Information}

The Supporting Information is available free of charge on the ACS Publications website. Photophysical data, computational procedures, X-ray crystallographic data, NMR spectra.

\section{AUTHOR INFORMATION}

\section{Corresponding Authors}

* E-mail: muriel.hissler@univ-rennes1.fr

*E-mail: nyulaszi@mail.bme.hu

*E-mail: pierre-antoine.bouit@univ-rennes1.fr

\section{ORCID}

Pierre-antoine Bouit: 0000-0002-0538-9276

\section{Muriel Hissler: 0000-0003-1992-1814}

\section{Notes}

All authors have given approval to the final version of the manuscript.

\section{ACKNOWLEDGMENT}

Financial Support from OTKA NN 113772 and BMENanonotechnology FIKP grant of EMMI (BME FIKP-NAT) for LN are gratefully acknowledged. ANR-16-CE05-0003-01, Heterographene, China-French AIL in "Functional Organophosphorus Materials", PICS SmartPAH (08062), PHC Balaton (38522ZH), EU-COST network CM1302 "Smart Inorganic Polymers" (SIPs) are also thanked.

\section{REFERENCES}

(1) Wu, J.; Pisula, W.; Müllen K. Graphenes as potential material for electronics. Chem. Rev. 2007, 107, 718-747.

(2) Figueira-Duarte, K.; Müllen, K. Pyrene-based materials for organic electronics Chem. Rev., 2011, 111, 7260-7314.

(3) (a) Ji, L.; Edkins, R. M.; Lorbach, A.; Krummenacher, I.; Brückner, C.; Eichhorn, A.; Braunschweig, H.; Engels, B.;
Low, P. J.; Marder, T. B. Electron Delocalization in Reduced Forms of 2-(BMes2)pyrene and 2,7-Bis(BMes2)pyrene. J. Am. Chem. Soc. 2015, 137, 6750-6753. (b) Crawford, A. G.; Dwyer, A. D.; Liu, Z.; Steffen, A.; Beeby, A.; Pålsson, L.-O.; Tozer, D. J.; Marder, T. B., Experimental and theoretical studies of the photophysical properties of 2- and 2,7-functionalized pyrene derivatives. J. Am. Chem. Soc. 2011, 133, 13349-13362. (c) Mateo-Alonso, A. Synthetic approaches to pyrene-fused twistacenes Eur. J. Org. Chem. 2017, 7006-7011; (d) Baumgärtner, K.; Kirschbaum, T.; Krutzek, F.; Dreuw, A.; Rominger, F.; Mastalerz, M. K-region-extended [c]-heteroannulated pyrenes Chem. Eur. J. 2017, 23, 17817-17822; (e) Mallesham, G.; Swetha, C.; Niveditha, S.; Mohanty, M. E.; Babu, N. J.; Kumar, A.; Bhanuprakash K.; Rao, V. J. Phosphine oxide functionalized pyrenes as efficient blue light emitting multifunctional materials for organic light emitting diodes $J$. Mater. Chem. C 2015, 3, 1208-1224; (f) Chua, C. J.; Ren, Y.; Baumgartner, T. Structure-property studies of bichromophoric, PAH-functionalized dithieno[3,2-b:2',3'-d]phospholes Organometallics, 2012, 31, 2425-2436; (g) Mateo-Alonso, A. Pyrenefused pyrazaacenes: from small molecules to nanoribbons Chem. Soc. Rev., 2014, 43, 6311-6324; (h) Feng, X.; Hu, J.-Y.; Redshaw, C.; Yamato, T., Functionalization of pyrene to prepare luminescent materials-typical examples of synthetic methodology. Chem. Eur. J. 2016, 22 (34), 11898-11916; (i) Lee, J.; Park, J., Synthesis and electroluminescence of novel pyrenefused chromophores. Org. Lett. 2015, 17, 3960-3963. (j) Ji, Lei; Lorbach, A.; Edkins, M. R.; Marder, T.B., Synthesis and photophysics of a 2,7-disubstituted donor-acceptor pyrene derivative: an example of the application of sequential Ir-catalyzed $\mathrm{C}-\mathrm{H}$ borylation and substitution chemistry. J. Org. Chem. 2015, 80, 5680-5665.

(4) (a) Zhang, S.; Qiao, X.; Chen, Y.; Wang, Y.; Edkins, R. M.; Liu, Z.; Li, H.; Fang, Q. Synthesis, structure, and opto-electronic properties of regioisomeric pyrene-thienoacenes $\mathrm{Org}$. Lett. 2014, 16, 342-345; (b) Zhang, S.; Chen, Y.; Liu, Z.; Fang, Q. Synthesis, structure and photophysical properties of regioisomeric sulfone-bridged pyrene-thienoacenes J. Photochem. Photobiol. A, 2015, 311, 25-29; (c) Luo, C.-E.; Ding, Z.; Wu, X.-W.; Liu, Z. Synthesis, structures and photophysical properties of two regioisomeric phenalenocarbazoles Spectrochim Acta A: Mol. Biomol. Spectrosc., 2018, 194, 111-116.

(5) (a) Hissler, M.; Dyer, P. W.; Réau, R., Linear organic p-conjugated systems featuring the heavy Group 14 and 15 elements. Coord. Chem. Rev. 2003, 244, 1-44.; (b) Joly, D.; Bouit, P. A.; Hissler, M., Organophosphorus derivatives for electronic devices. J. Mater. Chem. C 2016, 4 (17), 3686-3698.; (c) Duffy, M. P.; Delaunay, W.; Bouit, P. A.; Hissler, M., [small pi]-Conjugated phospholes and their incorporation into devices: components with a great deal of potential. Chem. Soc. Rev. 2016, 45, 5296-5310; (d) Ren, Y.; Baumgartner, T., Combining form with function - the dawn of phosphole-based functional materials. Dalton Trans. 2012, 41, 7792-7800.; (e) Matano, Y.; Imahori, H., Design and synthesis of phosphole-based pi systems for novel organic materials. Org. Biomol. Chem. 2009, 7, 1258-1271.; (f) Zhan, X.; Barlow S.; Marder, S. R. Substituent effects on the electronic structure of siloles Chem. Commun. 2009, 1948-1955; (g) Yamaguchi, S.; Xu C.; Tamao, K. Bissilicon-bridged stilbene homologues synthesized by new intramolecular reductive double cyclization J. Am. Chem. Soc. 2003, 125, 13662-13663; (h) Benkő, Z. Nyulászi, L. Top. Heterocyclic Chem. 2009, 19, 27-83; (i) Szücs, R.; Bouit, P.-A.; Hissler, M.; Nyulászi, L., Edge modification of PAHs: the effect of embedded heterocycles on the aromaticity pattern Struct. Chem. 2015, 26, 1351-1357.

(6) (a) Baba, K.; Tobisu, M.; Chatani, N., Palladium-catfalyzed direct synthesis of phosphole derivatives from triarylphosphines 
through cleavage of carbon-hydrogen and carbon-phosphorus bonds. Angew. Chem. 2013, 125, 12108-12111.; (b) Kuninobu, Y.; Yoshida, T.; Takai, K., Palladium-catalyzed synthesis of dibenzophosphole oxides via intramolecular dehydrogenative cyclization. J. Org. Chem. 2011, 76, 7370-7376. (c) T Ureshino, T.; Yoshida, T.; Kuninobu, Y.; Takai, K., Rhodiumcatalyzed synthesis of silafluorene derivatives via cleavage of silicon-hydrogen and carbon-hydrogen bonds. J. Am. Chem. Soc. 2010, 132, 14324-14326.

(7) Casas-Solvas, J.M.; Howgego, J. D.; Davis, A. P. Synthesis of substituted pyrenes by indirect methods Org. Biomol. Chem., 2014, 12, 212-232

(8) (a) Turro, N. J.; Ramamurthy, V.; Scaiano, J. C. Principles of Molecular Photochemistry, An Introduction; University Science Books: Sausalito, CA, 2009. (b) Birks, J. B. Photophysics of Aromatic Molecules; Wiley-Interscience: London, 1970.

(9) Romain, M.; Quinton, C.; Roisnel, T.; Jacques E. Rault-Berthelot, J.; Poriel, C; A Dihydrodinaphthoheptacene J. Org. Chem. 2018, 83, 1891-1897.
(10) (a) Narita, A.; Wang, X.-Y.; Feng, X.; Müllen, K., New advances in nanographene chemistry. Chem. Soc. Rev. 2015, 44, 6616-6643.; (b) Stępień, M.; Gońka, E.; Żyła, M.; Sprutta, N., Heterocyclic nanographenes and other polycyclic heteroaromatic compounds: synthetic routes, properties, and applications. Chem. Rev. 2016, 117, 3479-3716. (c) Szücs, R.; Bouit, P.-A.; Nyulászi, L.; Hissler, M., Phosphorus-containing polycyclic aromatic hydrocarbons. ChemPhysChem 2017, 18, 2618-2630.

(11) (a) Crawford, A. G.; Liu, Z.; Mkhalid, I. A. I.; Thibault, M.H.; Schwarz, N.; Alcaraz, G.; Steffen, A.; Collings, J. C.; Batsanov, A. S.; Howard, J. A. K.; Marder, T. B., Synthesis of 2- and 2,7-functionalized pyrene derivatives: an application of selective C-H borylation. Chem. Eur. J. 2012, 18, 5022-5035.; (b) Baillie, C.; J. Xiao Palladium-catalysed synthesis of biaryl phosphines Tetrahedron 2004, 60, 4159-4168; (c) Lamale, B.; Henry, W. P.; Daniels, L. M.; Zheng, C.; Klein, S. M. Jiang, Y. L. Synthesis and crystal structures of fluorescent receptors for 9-butyladenine Tetrahedron 2009, 65, 62-69 